\title{
HETEROTOPIA AND ALIENATING LIMINAL SPACES IN ULYSSES DUBLIN ${ }^{1}$
}

Maryam Najafibabanazar ${ }^{2}$

\begin{abstract}
The main focus of this article is to analyze how physical spaces and landscape are employed to reflect and represent alienation and isolation of individuals in Ulysses and to specify how alienation is textually encoded in the form of the novel through the places and spaces which mostly are liminal. The protagonists of U/ysses are reflecting a deep sense of spatial alienation in their own descriptions of physical spaces. It is noticeable that in this novel the idea of alienation is encoded in all of Dublin's places and spaces, and this use of places as markers of, or embodiments of alienation, shapes the form of the novel as alienating, too: the form of Ulysses has been shown to be molded around the unhomed wanderings of Stephen and Bloom around Dublin. Joyce's representation of alienation is multiplex and more predominantly a social alienation, where, although there is an active social life in Dublin, the individuals lead alienated lives within an isolated city in a marginalized and colonized island. These people's psychological alienation comes along with their historical, political, cultural, and physical isolation and exilic states. Thus, it is possible to claim that Joyce projects his sense of alienation and all the Dubliners' sense of estrangement in Stephen's and Bloom's dislocation and Ioneliness in their hometown.
\end{abstract}

Keywords: Alienation, Liminality, Ulysses, Liminal Spaces, Heterotopia, James Joyce.

\section{Liminality and Alienation}

There are many different ways in which the main characters of Ulysses (1922) are shown as alienated from their societies, and how the protagonists in the novel directly and indirectly communicate and express their senses of isolation and disconnection from their communities. This article examines what is modernist about the places and (urban and non-urban) spaces in Ulysses, and investigates in what ways they are alienated or alienating, and how this alienation is encoded and reflected in this modernist novel by the Irish novelist, James Joyce. This article will thus start with a discussion of spatial alienation and urban life in the city which is significant in studying modernist literature. Then, because the spaces in Ulysses are very frequently liminal spaces, particular attention is paid to liminality. Liminality by definition talks about two sides, one leading in, and one leading out. Thus, familiarity

\footnotetext{
${ }^{1}$ This article is a brief excerpt of a chapter in my Ph.D. thesis titled: "Literary Encoding of Modernist Alienation in The Language and Spaces of James Joyce's Ulysses and Sadeq Hedayat's The Blind Owl", METU, 2018.

${ }^{2}$ Dr., Bilkent University, maryam.najafi86@gmail.com, mary.najafi@bilkent.edu.tr, https://orcid.org/0000-00017117-5383.
} 
and integration, as well as alienation and possible rejection or exile are studied and analysed. Both of them are indicated by the spaces dominant in the novel of this study. It is also possible to observe Dublin in terms of liminal stages and transitional spaces that exist in between being modern or non-modern. The novel represents this state of in-between-ness and uncertainty as causing alienation and a sense of separation from their surroundings in the characters as a result of the peripherality of their geographical situation.

Before diving into the discussions about liminality and alienation, it is important to note that, this article does not focus on the debates about precise definitions of space and place. For the purpose of this research, a definite distinction is made between the notion of place as a physical entity like city, building, house, room, kitchen, a "static sense of location, of being, of dwelling," and space, which usually refers to something more abstract (Thacker 13). Space, and liminal spaces, in this study, refer to the conceived spaces rather than a concrete concept. Liminal spaces like the thresholds of windows and doorways, as well as spaces like heterotopias are, oftentimes, mentally constructed.

The focus on city, urban life, and urban consciousness is part of the common characteristics of modernist literature and modernist fiction in particular (Childs 19). Whitworth also states that "modernist literature depicts modern life, especially urban life," (11) and, according to Simmel, it is in the metropolis that "a different amount of consciousness" (184) of the human being is extracted when compared to rural life. In other words,

the metropolitan type of man - which, of course, exists in a thousand individual variants - develops an organ protecting him against the threatening currents and discrepancies of his external environment which would uproot him. He reacts with his head instead of his heart. In this an increased awareness assumes the psychic prerogative. Metropolitan life, thus, underlies a heightened awareness and a predominance of intelligence in metropolitan man. (Simmel 184)

Thus, when the focus is on the consciousness of the individuals in modernist fiction in a modern (urban) location, studying how urban places would or could reflect the alienation of the characters is a suitable strategy for the study of texts like Ulysses which is set in Dublin. On the other hand, the places in the novel, regarding whether they are urban, as what we see in Dublin, or they are partly urban and partly rural, 
could reveal political and social characteristics of the novel as we will observe. These social and political characteristics- the colonial conditions in Ireland for instanceare themselves alienating and have estrangement effects on the individuals in the novel. The significant issue in studying place, space, and individuals' consciousness in modernist literature would be to state that "considerations of the city and modernism have increasingly been framed by the idea that space does not have an independent existence, but is socially constructed" (Simmel 199). These social constructions cause alienation for the characters, as we will see in Ulysses and through the focus on the textual representations of alienation and how Joyce has embedded alienation in the text.

Liminality embodies ambivalence and ambiguity and thus complicates any sense of purpose or direction, and in this, it resembles some characteristics of modernism, for "[a] tendency towards ambiguity, paradox and an uncertain surface structure is also peculiar to some of the characteristic aims of modernist literature" (Drewery 48). Experiencing this state of uncertainty, feeling embedded or trapped in a liminal space, can cause a sense of alienation and isolation. The state of liminality having a multidirectional relationship, each direction feeding off each other, could be the primary reason for the perplexity and emotional dangling of characters; thus belonging to all or no "sides" in itself causes a situation that demonstrates a kind of alienation. Liminality relates essentially to a transitory state, a threshold, and something at a boundary, a state of in-between-ness. The uncertainty that is embedded in the concept of liminality is what makes it related to the modern experience as also to postmodernity. This is cogently summarized by Thomassen, who writes that "there are evident reasons that discussion of liminality in contemporary [literature] almost inevitably leads to the core of the modern project which is one of constant overcoming of boundaries and questioning of authorities and the taken-for-granted" (3). Thus, boundary-transgressing issues, which are central in liminality and liminal situations, are also encountered in the modern context. Thomassen further states that liminality in essence deals with "dissolving any fixity of position, dissolving the modern into permanent hybridity" (8). Considering the general agreement that being modern is "essentially about rationalizing, measuring, and categorizing" (9-10), being modern can be seen to value boundaries. That may be why liminality is so particularly alienating in modernist fiction; this is quite different from the conception of liminality in postmodernity and its fiction, which is concerned with "the liberation of genres and 
going beyond the boundaries" (9). For modernists, what we now perceive of as liminality (a word and concept they, themselves, did not theorize) ${ }^{3}$ is thus about the problem of leaky and fuzzy boundaries that are perceived as necessary for "rationalizing, measuring, and categorizing (9), and therefore in spite of the blurriness of in-between spaces, they are often represented in concrete images such as entrances and exits, borders and crossings, which in fact relate to their etymological origins (from Latin limen, "threshold"). The state of liminality and instability that causes dislocation, displacement and alienation of the individual in a modern/modernist context has also been incorporated in a postmodern worldview, where it is dealt with an unavoidable state of flux, of going backwards and forwards across boundaries.

Making a distinction between some phrases which connate ambiguity, uncertainty and in-between-ness, in different contexts, prevents misconceptions of the notions of liminality and liminal situations, as they will be referred to in this article, and for this purpose, Drewery's explanation below can be defined as sufficient. Drewery indicates a distinction between marginality, inferiority, and liminality by stating that marginality is

a condition of being peripheral or minor, exists at the edges of social structure, whilst inferiority implies disempowerment and is situated beneath it. Liminality differs in that it exists within social structures itself, but in its interstices; the cracks falling between pre-existing social norms, classifications, and conventions. (3)

What will be dealt with in this article is the idea of liminal situation and characters which are falling in nowhere category in the novel. Some common liminal images and spaces usually include doors, windows, mirrors, candles, curtains, gateways, shorelines and the tomb (Drewery 11). These liminal spaces and images are the ones which will be encountered and analysed in the novel of this study and the focus will be on how these images of liminality and alienation are reflected textually by the author.

In addition to the liminal spaces in Ulysses, which powerfully indicate a modern sense of alienation and a sense of not, or not fully, belonging to the spaces

\footnotetext{
${ }^{3}$ Although T. S. Eliot's The Waste Land could be argued to be the Modernist poetic analysis of liminality in most of its aspects.
} 
and locations of Dublin, there are many enclosed spaces in the novel that perform the same functions. The examination of places encoding alienation (and related states) in the novel now turns to the enclosed spaces of Ulysses, like its houses, hospitals, post offices, newspaper bureau and advertisement offices, and shops. It will be argued that not only the protagonists but most of the characters in Ulysses are separated from enclosed spaces in Dublin, even though they commute to these places. Stephen Dedalus is alienated from and physically leaves his father's house and his rented tower. He also feels isolated and detached from the school he teaches in during working hours. On the other side of Dublin, Leopold Bloom is similarly disconnected from his house and family life, although he has not left them permanently. Although he and his wife Molly share the same house and bed, it is understood that they have difficulty in communicating their emotions toward each other and at every level of their relationship they are alienated from each other.

In The Poetics of Space, Bachelard studies how enclosed sites like homes may provide the space, ignite the imagination, and prepare the mind for daydreaming, introspection, and self-analysis. In his analysis of space, Bachelard, as noted by Thacker, focuses upon spaces that "have been turned into places of pleasurable belonging, the transformation of house into home, where the rooms and corridors of the house articulate the topography of our intimate being" (Thacker 5). Furthermore, when a person feels isolated in a place, that person may start daydreaming and use that daydreaming, nevertheless, as an alternative space of refuge and living. Bachelard believes that "all really inhabited space bears the essence of the notion of home" (Bachelard 5). John R. Stilgo in the introduction to this book also states that Bachelard's purpose is to show that "the house is a nest for dreaming, a shelter for imagining" (viii). For Bachelard, a house is perceived as "place-world, a world of places" (Casey 291), and it is a place "where the exploration is not so much geometrical or architectural as imaginative or poetic" (Thacker 15). Thus, for Bachelard situated daydreaming has connotations for imagining, memories, and inspirational moments because the imaginative part of the mind is close to the unconscious. Besides this, he argues that the mechanism for daydreaming comes into existence naturally when the subject is in a suitable space. According to Bachelard this happens as a process in which the imagination

functions in this direction whenever the human being has found the slightest shelter: we shall see the imagination build "walls" of impalpable 
shadows, comfort itself with the illusion of protection-or, just the contrary, tremble behind thick walls, mistrust the staunchest ramparts. In short, in the most interminable of dialectics, the sheltered being gives perceptible limits to his shelter. He experiences the house in its reality and in its virtuality, by means of thought and dreams. (5)

Thus, the necessary ingredients or components for a daydream are a shelter or any space functioning somehow like a nest, and a solitary person. In other words, an alienated person may use an enclosed space for daydreaming and introspection whether it is a home or only somewhere that slightly resembles a home. This daydreaming can occur when a person is comfortable in that space or on the contrary when $\mathrm{s} /$ he feels alienated and separated from that place. Similarly, daydreaming may well be used in comfortable places or as a retreat for an alienated person from his surroundings. For Bachelard, "the house is one of the greatest powers of integration for the thoughts, memories, and dreams of mankind" (6). Many characters in Joyce's Ulysses, such as Stephen, Dilly, and Simon Dedalus, and Leopold Bloom, are wandering and daydreaming outside of houses. Therefore, Bachelard's notion of the functional role of a house as a place for daydreaming underscores the alienation represented by characters who are daydreaming "out of place," as it were, and whose daydreams are thus, in some ways, detached from the necessary surrounding and nurturing environments. The 'unhomed' characters of Ulysses, like Stephen and Bloom, who are nevertheless daydreaming, present a poignant contrast to these preconditions of Bachelard's daydreamer, and in this way their alienation is all the more evident. They still daydream, but outside of the spaces, that (as Bachelard would claim) are normal, and nurturing and, in a way, protective of daydreamers.

\section{Heterotopia and Alienation}

The idea of heterotopia as the place of otherness is also studied in this article and it also presents an examination of enclosed spaces as loci of speculation and daydreaming, and these issues are discussed in terms of the alienation and isolation of individuals in Ulysses. By referring to Foucault's ideas about places of otherness which he names heterotopia (and also utopia which is not relevant to the main ideas and aims of study), alienating situations and the alienation of characters in Joyce's novel will be studied. Foucault states that heterotopia's role "is to create a space that is other, another real space, as perfect, as meticulous, as well arranged as ours 
is messy, ill constructed, and jumbled" (8). Characters like Bloom create their own heterotopias to compensate for their senses of isolation and alienation. Bloomusalem and the brothel in Ulysses are good examples of heterotopias of compensation where social and psychological alienation of Bloom is embedded and depicted in other spaces he builds in his mind/hallucination and parallel to Dublin's real places and spaces. It is through the scene in the brothel and the surreal dreams in "Circe" Chapter that Bloom's and, to some extent Stephen's, alienation is represented and revealed. Bloom builds and employs parallel spaces in his mind and dream to, at least temporally, take control and exert power on his surroundings.

All the main characters in Dublin's streets are walking in outwardly familiar places and spaces; however, there is a sensibility of isolation and alienation in their wanderings. For Bloom, some streets are still pleasing and amiable. One very important street for him is Eccles Street, where he lives at No. 7. For Bloom, Eccles Street, and in a way, all of Dublin's streets can be considered liminal and transitional. This liminality is related to Bloom's longing for a "hurrying homeward" (Joyce 73) and the same time his pleasure in leaving and avoiding his house and wandering around Dublin. Bloom's sense of existential alienation is observable in his doubts and longings for another place to live. His desire to live in an imaginary promised land is an example of "obstacle[s] to individuals' ability to understand the world as their own" (Jaeggi 9-10). Bloom is wandering in the streets of Dublin, in between his home and the rest of Dublin, and he is, both mentally and physically, alienated and isolated. Thus, Eccles Street is a house but not a home, and Dublin is part of his country, but it is not the ideal home of his fantasies. It appears to be a powerfully liminal space for Bloom, representing his alienation and his possible incorporation into a household and family life.

Bloom's job of doing "some canvassing for ads" (Joyce 134), which refers to advertising that has been seen as a symbol of the modernization of the 1904 Dublin (Hayward 663), is also closely related to his wandering and moving freely in Dublin city. "The heart of Hibernian metropolis" (147) is Bloom's transitional space; even so, while he is living in Dublin, he very frequently daydreams about his other homeland, Israel, and about his dreamland, that he (in somewhat Joycean fashion) calls "Bloomusalem" (Joyce 606). This daydreaming about another homeland, this mental inhabiting of another space, creates a sense of alienation and separation from his physical space of living. According to Foucault, such parallel places are 
called heterotopias. He claims that

there are ... probably in every culture, in every civilization, real placesplaces that do exist and that are formed in the very founding of society which are something like counter-sites, a kind of effectively enacted utopia in which the real sites, all the other real sites that can be found within the culture, are simultaneously represented, contested, and inverted. Places of this kind are outside of all places, even though it may be possible to indicate their location in reality. Because these places are absolutely different from all the sites that they reflect and speak about, I shall call them, by way of contrast to utopias, heterotopias. (3-4)

In Foucault's notion, heterotopias have two functions, they either "create a space of illusion" or they exist as "compensation" (Foucault 8). Bloom creates his heterotopias as both an illusionary space and a compensatory one, as one can claim, to escape the state of alienation he experiences in the social and external spaces in Dublin. For Bloom, Dublin and its streets are thus a liminal space lying between his fantasized sense of (be)longing to/for another homeland and another city, and his real sense of alienation in his present location. Nonetheless, Bloom is shown to be more willingly associated with the places and spaces in Dublin than Stephen is; for Bloom, there are still some warm and pleasant streets, such as Eccles Street where his house is located. This has its correlate in the Dublin of his emotions, for even though he is constantly daydreaming about other places and spaces, Bloom retains some ties and attachment to his frail and problematic family life and to the onetime love (Molly) he has in Dublin.

Bloom's experience of heterotopia, his desire for another imaginary place, in addition to his freedom and ease of movement in Dublin and out of Dublin in his daydreams, may well reflect his social alienation (Schacht's notion of lack of interpersonal relationships (157) fits Bloom's sense of alienation) in Dublin, where some Dubliners like the "Citizen" state that they "want no more strangers" in their house and country (Joyce 719-20). Bloom is still considered a converted Jew and a stranger in his hometown and far from "experiencing a crystallized totality" based on theories of social alienation (Kalekin-Fishman 6). "Is he a Jew or a gentile or a holy Roman or a Swaddler or what the hell is he? Says Ned. Or who is he? ... we don't want him" (Joyce 438). For Dubliners like the "Citizen" Bloom is a "perverted Jew" as Martin says when he describes Bloom (Joyce 438) from somewhere in 
Hungary. In spite of all the seeming nets and borders- like him being considered a converted Jew and a foreigner from Hungary claiming to be an Irishman (Joyce 430)existing around Bloom's identity, he can and will daydream about where he desires to live. The Bloomusalem in Bloom's mind is constructed as a result of the liminality of his status and the alienation he feels in Dublin. He even visualizes the shape and details of Bloomusalem, as a space of illusion as well as a compensation for his present site of living, which will be discussed, in more detail, in the following part about enclosed edifices.

However, there are images and textual representations of liminality, marginality, and alienation in the scenes where tramlines pass or do no pass. For instance, in Chapter 15 "Circe", which can be considered as the chapter occupying the most marginal and liminal space of the city, the Nighttown of Dublin, the narrator mentions that the tramline passes by the area and not through it. This is a direct reference to the political and ideological schemes that lay behind the building of the tramline in a colonial city like Dublin. Lanigan records that it was mapped in order to prevent the tramline from passing through problematic or poor neighborhoods. Exclusion from the tramway system also, of course, rendered these places even more liminal and marginal in terms of access, as well as of status. In other words, the tram-lines were designed not to pass through poverty-stricken areas or areas such as the red district of Dublin at the time; thus, it can be said that the tramline in itself created a sense of isolation for the residents or the commuters to those estranged areas.

The trams were often too expensive for Dublin's working classes to use, and their routes frequently skirted or avoided the areas of greatest poverty. ... on the north side of the city, ... trams ran on Talbot Street, Summerhill, and Sackville Street; that is, three sides of the red light district, but at no point through it. The tram system, then, was removed from areas of the city that were problematic, and also served to reduce the propensity for random encounters with the urban environment through which ideological views of the city as the locus of progress could be called into question. (Lanigan 41)

This is a liminal space where Bloom and Stephen's repressed desires are unleashed in the shape of hallucinatory dreams. A brothel, in Foucault's terms, is a perfect example of heterotopia, which "exposes every real space, all the sites inside of which human life is partitioned, as still more illusory (perhaps that is the role that 
was played by those famous brothels of which we are now deprived)" (Foucault 9). The brothel frequenters, whether visitors or workers, are also liminal and alienated in that space. They are not part of the formally mapped space of the city life, however, they have their own life on the margins of the city. In Foucault's heterotopias, as alternative spaces in relation to real places, "power is implied since heterotopia inverts and contests real sites" (Thacker 29); thus, it is possible to say that heterotopias are spaces of at least partial freedom and, as in the cases of Stephen, Bloom, and the brothel, they are examples of the spaces of resistance to the "dominant socio-spatiality, found in marginal places and locations" (Thacker 29).

In his book, Bachelard introduces his concept of "topoanalysis," which he defines as the systematic psychological studying of the sites of our intimate lives. The house, the most intimate of all spaces, "protects the daydreamer" and therefore understanding the house is for Bachelard a way to understand the soul. ${ }^{4}$ In this way, the characters in Ulysses, reveal their souls and their senses of alienation or integration in the most intimate aspects of their lives when they daydream or talk about their homes.

Even outside of the domestic space, there are some strong images, like Bloom's imaginary Bloomusalem, functioning and operating like heterotopias as a space of compensation, in each one of our imaginations. These "successfully separate the daydreamer[s] from the restless world, and give [them] an impression of domination at little cost" (Bachelard173). This is what is applicable to the main characters in Ulysses; Bloom and Stephen frequently get distracted and fall into the daydreaming world, that is "the world of high solitude" (173). Thus, the enclosed spaces in Ulysses may well initiate the daydreaming and reveal part of the psychological and social alienation of the characters.

As mentioned in Bachelard's theory of space, not only personal homes but any enclosed place that inspires the sense of home allows space for dreaming and introspection. Both Stephen and Bloom have their own series of daydreaming in Ulysses. It is partially because of their solitude and social alienation that these spaces, whether it is their homes, school, or a brothel, provide them with and shape daydreams, through which they distinctly reflect the alienation of their minds. Stephen Dedalus chooses an isolated and liminally positioned tower as an escape

\footnotetext{
${ }^{4}$ http://culturalstudiesnow.blogspot.de/2011/06/gaston-bachelard-poetics-of-space.html
} 
and residence. The tower could have embodied the notion of a home; but Stephen is deprived of having or he deprives himself of having this nest-like space. He deliberately, alienates himself from his father's house and rejects to live with his father and other siblings. Stephen also decides not to return to the rented tower (the old tower on Sandymount where Stephen's friend Buck Mulligan forces himself on Stephen's privacy and self-chosen isolated home. Stephen, as understood from the novel, will not go back to work for the school he used to teach there. He chooses to alienate himself from every enclosed space that may give him the sense of a house. He chooses the physical and spatial isolation that appears to be what he feels in his mind and sensibility while professing his "non serviam" ideology. Even though Stephen states he does not have any place to sleep in, he rejects Bloom's offer of a place to stay overnight, for instance. Stephen needs spaces for introspection and self-analysis, but he alienates himself from suitable places and, specifically, from his living spaces. When he starts daydreaming about his artistic ambitions, the uncertainty and ambivalence in his ambitious ideals are what could be called his modern sensibility. Stephen does not feel the sense of belonging to the liminal and enclosed places he is living in. Or in other words, the liminal spaces he inhabits are depicted so as to convey his senses of non-belonging and alienation.

The enclosed places and edifices within this novel are, in fact, another way in which the places of Ulysses textually embody and encode the concept of alienation. The creation and construction of "the new Bloomusalem in the Nova Hibernia of the future" (Joyce 606) in Bloom's daydreams, with all the details of the immensity of the place, could thus stand for the hugeness of his sense of isolation in Dublin. Besides, in Foucault's theorization, Bloomusalem is a compensation heterotopia where its "role is to create a space that is other, another real space, as perfect, as meticulous, as well arranged as ours is messy, ill constructed, and jumbled" (8). Bloom depicts this fantasy place as

a colossal edifice, with crystal roof, built in the shape of a huge pork kidney, containing forty thousand rooms. In the course of its extension several buildings and monuments are demolished. Government offices are temporarily transferred to railway sheds. Numerous houses are razed to the ground. The inhabitants are lodged in barrels and boxes, all marked in red with the letters: L.B. several paupers fall from a ladder. (606)

This daydreaming, as Bachelard also states, allows and creates another 
space. It is one in which Bloom feels that he is the dominant and most powerful figure, and all the places and people that make him feel alienated in his experienced Dublin are now marginalized or re-enclosed in different spaces where they are no longer threatening to him. What Bloom has in mind is not so much a Promised Land, but a Promised Palace. It is significant that his memory-dream, in which he will no longer feel alienated and isolated, and which is formed by his needs for compensation, takes the form not of a country or city, but an enclosed (sheltered), if enormous, place. This idea of daydreaming of other places is another typical sign of alienation and isolation in Bloom's case. The depth of solitude in Bloom's life is reflected in his isolation and alienation from the urban space he is wandering around. Thus, he has to dream about another place, a sheltered heterotopia in which he feels more at home and where he has marginalized or imprisoned (in boxes and barrels) all the elements that most cause his sense of alienation. In his daydreamcreated space, he feels recognized and accepted. It is in this heterotopia of compensation that he is accepted and he is strong; he is attributed such power that he is given the keys to Dublin and becomes the ruler of the city (Joyce 606); he is introduced to the people of the city as: "that's the famous Bloom now, the world's greatest reformer. Hats off!" (Joyce 604), "he's a man like Ireland wants" (Joyce 606). Besides, it is in this heterotopia that Bloom feels strong enough to have "repudiated" his "former spouse" and tragi-comically enough he has "bestowed" his "royal hand upon the princess Selene, the splendour of night" (Joyce 605). It is only in this space of heterotopic compensation and strength that the Citizen who earlier in the day had degraded Bloom and insulted him, is now praising him as the reformer of Ireland: "Citizen: (Choked with emotion, brushes aside a tear in his emerald muffler) May the good God bless him!" (Joyce 608-9). This heterotopia of compensation with all its details thus, through having created a complete opposite to what distresses him, embodies Bloom's sense of social and psychological alienation and his isolation throughout the text. Blades declares that Bloom's alienation is in fact the focus of the novel and "the central chapters of the novel emphasize this impression of his alienation amidst the teeming life of the city" (140).

Another lonely space for Bloom is the enclosed space of his house, his kitchen, and more significantly, his bedroom. He seems to create other places, i.e. heterotopias alongside his house, too. He has a secret correspondence, under a pen name (Henry Flower), with some other woman. He creates a parallel space for love and his sexuality. He even starts masturbating at the Sandymount shore, while he is 
gazing at Gerty MacDowell. Furthermore, remembering Bachelard's notion that enclosed and "inhabited" places ignite the daydreaming sense (5), the enclosed space of the Blooms bedroom, reveals Molly Bloom's depth of alienation and she expresses her desires and concerns, through interior monologue, and when she is in her bedroom and the reader meets her in the closing Chapter of the novel. Her sexual desire and her frustration concerning her relationship, her son's death, and her daughter's life in another city are all revealed in her interior monologue. She has that comfort to open up her mind and heart in her bedroom. The bedroom is the place in which she returns to her marriage and marital life. One may well claim that her soliloquy is a kind of daydreaming in which she reflects what is happening in her mind while she has been excluded from the dialogues and absent during Bloom's wandering in Dublin. Then she brings to center the bedroom that was kept at the periphery all along the story and all along that day in Ulysses.

The main idea behind the researched topic in this article has shown that, when it comes to the notion of separation, mental alienation and liminality, the senses of separation, isolation, and alienation are embedded in the text of Ulysses and are reflected in the explanations of the space, provided by the characters. Alienation of the characters and marginality of locations are encoded and embodied through the places and spaces of Dublin, rather than just through the themes or the isolated mental and social state of the protagonists. Joyce's type of alienation, is multiplex and more predominantly a social alienation, where, although, there is an active social life in Dublin, the individuals lead alienated lives within an isolated city in a marginalized and colonized island. These people's psychological alienation comes along with their historical, political, cultural, and physical isolation and exilic states. Thus, it is possible to claim that Joyce projects his sense of alienation, and all the Dubliners' sense of estrangement in Stephen's and Bloom's dislocation and loneliness in their hometown. There is also, however, an argument to be made that it is Dublin's alienation that dominates and pervades the novel; after all, Joyce had always intended to write about Dublin, as he stated "because if I can get to the heart of Dublin I can get to the heart of all the cities of the world. In the particular is contained the universal." 5 This article has shown that the representation of the physical spaces in and around the sites of Ulysses makes the novel as much about the city alienated within the modern context of the setting of the novel as they are

\footnotetext{
${ }^{5}$ Quoted in Ellmann, James Joyce, 1965 Edn., p.520, citing interview with Arthur Power, Dec. 1953
} 
about the alienated characters that inhabit them.

\section{WORKS CITED}

Bachelard, Gaston. The Poetics of Space. Translated by Maria Jolas, Boston: Beacon Press, 1958.

Blades, John. How to Study James Joyce. London: Macmillan, 1996.

Casey, S. Edward. The Fate of the Place. A Philosophical History. Berkeley CA: University of California Press,1998.

Childs, Peter. Modernism. $2^{\text {nd }}$ ed. New York NY: Routledge, 2008.

Drewery, Claire. Modernist Short Fiction by Women: The Liminal in Katherine Mansfield, Dorothy Richardson, May Sinclair and Virginia Woolf. New York NY: Routledge, 2016.

Foucault, Michel. "Of Other Spaces: Utopias and Heterotopias." ("Des Espace Autres," March 1967). Translated by Jay Miskowiec Architecture /Mouvement/Continuité, Oct., 1984.

Hayward, Mathew. "Bloom's Job: The Role of the Advertisement Canvasser in Joyce's Dublin." Modernism/modernity, vol. 22, no. 4, Nov. 2015, pp. 651- 666.

Jaeggi, Rahel. Alienation. Translated by Neuhouser, Frederick, and Alan E. Smith, Edited by Neuhouser, Frederick, New York NY: Columbia UP, 2014.

Joyce, James. Ulysses. London: Penguin Books, 1992.

Kalekin-Fishman, D., editor. Designs for Alienation. Jyvaskyla: University of Jyvaskyla Press, 1998.

Lanigan, Liam. “'Becalmed in Short Circuit': Joyce, Modernism, and the Tram.” Dublin James Joyce Journal, no. 5, 2012, pp. 33-48.

Schacht, Richard. Alienation. New York: Psychology Press, 2015.

Simmel, Georg. "The Metropolis and Mental Life". Kurt Wolff (Trans.) The Sociology of Georg Simmel. New York: Free Press, 1950, pp.409-424. https://condor.depaul.edu/dweinste/theory/M\&ML.htm

Stilgo, John, R., foreword. The Poetics of Space by Gaston Bachelard. Translated by Maria Jolas, Boston: Beacon Press, 1958.

Thomassen, Bjorn. Liminality and the Modern. Living Through the In- 
Between. Farnham: Ashgate, 2014.

Thacker, Andrew. Moving Through Modernity: Space and Geography in Modernism. Manchester: Manchester University Press, 2003.

Whitworth, H. Michael, editor. The Blackwell Guide to Modernism. Oxford: Blackwell, 2007. 